REVIEW ARTICLE

PRACA POGLĄDOWA

\title{
CONSTITUTIONAL AND ADMINISTRATIVE ASPECTS OF THE UKRAINE'S MEDICAL CODE
}

DOI: 10.36740/WLek202001136

\author{
Natalia V. Mishyna, Olena 0. Surilova \\ NATIONAL UNIVERSITY"ODESA ACADEMY OF LAW", ODESA, UKRAINE
}

\begin{abstract}
The aim of this study is to show which aspects of Ukraine's constitutional and administrative law should appear in Ukraine's future medical code. Materials and methods: The authors analyse five pieces of law or proposed law, including the 1996 Constitution's provisions on health care, Law the Fundamentals of Health Protection and the main codes. The authors apply classical legal analysis to these laws - analyzing the first three chapters of the proposed medical code from a constitutional and administrative perspective. The other methods used by the authors are systemic, comparative and synergetic. Conclusion: Ukraine needs a medical code incorporating international and European health care standards. Such a code will also further develop the country's medical legislation. Yet the proposed project has many constitutional and administrative weaknesses.
\end{abstract}

KEY WORDS: health care reform, medical code, public health, right to the medical assistance, right to the health care

Wiad Lek. 2020;73(1):191-195

\section{INTRODUCTION}

At present, the uncodified Ukrainian medical legislation's main drawback consists of its lack of constitutional and administrative basis. The country's parliament - the Verhovnya Rada - has yet to ratify the bill reforming the law Fundamentals of Health Protection ${ }^{1}$.

The government has adopted several previous laws. Some of the most recent examples include the 2005 President's Decree On Urgent Measures to Reform the Public Health System, 2007 National Plan for the Development of the Health Care System for the Period up to 2010, Plan of Law-Making Process for 2008, On Approval of the Program of Activities: Ukrainian Breakthrough: For People, Not Politicians (all approved by the Cabinet of Ministers). Therefore, the government has not revised or reformed - for a long time - regulations and administrative acts leading to the Medical Code's development.

\section{THE AIM}

The aim of this study is to show which aspects of Ukraine's constitutional and administrative law should appear in Ukraine's future medical code.

\section{MATERIALS AND METHODS}

The main materials of the research are the norms of the Constitution of Ukraine of 1996 concerning healthcare and those of interpretation, the decisions of the Constitutional
Court of Ukraine, the Civil Code of Ukraine, the draft Medical code of Ukraine - draft law "On Amendments to the Fundamentals of legislation on healthcare", the Concept of reform of financing the healthcare system, the Concept of development of the system of public health, the Code of Ukraine on Administrative Offences.

In the analysis of the norms of the Fundamental Law of Ukraine the authors used an axiological approach and primarily the systemic method to cover the norms of the first two sections, that concern protection of health; at that of importance were also the methods of analysis and synthesis. The technical legal and comparative methods have been used in comparison of norms of medical and administrative legislation of Ukraine, and the synergetic method enabled a new look at the state regulation of healthcare and the problem of elimination of controversies in normative and other legal acts.

\section{REVIEW AND DISCUSSIONS}

Ukrainian legal authors research mostly the civil law aspects of the proposed medical code. Experts propose to codify all of the civil law provisions related to health care [1]. Some local lawyers pay the utmost attention to the codification of Ukraine's civil procedural articles [2]. Researchers propose to modernize Soviet inspired health care and medical policy, using the civil law and Civil Code as the means - as legislators codified Ukraine's modern civil law after independence. They did not choose to use admin-

\footnotetext{
${ }^{1}$ The lawmakers refer to it as to the Medical Code, in this article the authors refer to it as to the 'proposed medical code'.
} 
istrative law reform, as Ukraine's Administrative Code still dates from Soviet times [3]. Some authors though, argue that international law, not the civil law, should provide the model for reform-as Ukraine has not ratified many international standards into its domestic legislation [4]. Textbooks in Ukrainian medical law follow current civil law norms, with teaching and instructional cases coming mostly from the civil law [5].

However, in these works, authors pay almost no attention to constitutional and administrative aspects of the proposed medical code. These experts in constitutional and administrative law almost do not research the constitutional and jurisprudential problems involved in codifying Ukraine's medical law. Saribayeva represents the exception, with her works looking at methods and consequences of systematizing the country's health care law [6]. This study shows which aspects of Ukraine's constitutional and administrative law should appear in Ukraine's future medical code.

As of the moment, the organization of healthcare system of Ukraine is incapable of guaranteeing the right of the citizens to quality medical assistance, therefore, the primary task of the Medical code of Ukraine is creation of legal foundations for state regulation of protection of public health, that would encompass not only provision of medical services, but also the system of environmental safety and improvement of social environment in the country. Therefore, it is necessary: first, to introduce necessary corrections in the names of sections, chapters and articles of the Medical code; secondly, to specify not only the powers of the bodies of state government and local self-government in the sphere of public health, but also their duties on guaranteeing the rights of the interested public in this sphere; thirdly - exclude the provisions on the procedure of licensing the medical activities, limiting them to indication of obligatoriness of licensing of certain types of such activity; fourth - improve the norms on procedure and conditions of application of influence methods, as long as they are the measures of civil, criminal, administrative responsibility which are applied in accordance with the procedure prescribed by law in case of a violation of the legislation on public healthcare.

1. The Constitutional Provisions of the Proposed Ukrainian Medical Code

Ukraine's constitution's authors created the foundation for the regulation of health issues in the country. The constitution guarantees the right to health care, medical care and medical insurance (art. 49). The supreme law also declares the country as a "social state" (art. 1). Moreover, the constitution provides that, "the person, his/her life and health, honor and dignity, inviolability and security are recognized in Ukraine as the highest social value. Human rights and freedoms and their guarantees determine the content and direction of the state's activities. The state is responsible to a person for his activities. The assertion and guarantee of human rights and freedoms is the main responsibility of the state" (art.3) [7].

In addition, a number of the 1996 Constitution's articles allow the government to restrict human rights in the inter- ests of public health. Examples include freedom of opinion and religion (art.35), the right to freedom of association in political parties and public organizations (art.36), the right to gather peacefully, without weapons and hold meetings and demonstrations (art.39).

The proposed medical code claims that health care legislation requires that "it [the legislation] is based on the Constitution of Ukraine" (art. 1). The proposed medical code further posits that, "Health care is the duty of the state, citizens and society" (the title of art. 2). The article further provides that, state bodies, local government, enterprises, institutions and organizations of all forms of ownership [as well as] officials, citizens and their associations are obliged to ensure the priority of health care in their own activities; not to harm the health of the population and individuals, to provide assistance to patients, disabled persons, victims of accidents and in the event of an emergency within the limits of their competence, to assist employees of health facilities in their work and perform other duties provided by law [8].

This article adequately reflects the transition from the Semashko model. This model envisaged full state financing of health care. The proposed medical code seeks to promote each person's own financial responsibility (with contributions made by the state) for his or her own health. Lawmakers wrote the article conforming to the two related constitutional court decisions on the health care. These decisions comprise the 1998 Decision on Case of the Paid Medical Services and the 2002 Decision on Free Medical Assistance $[9,10]$.

Lawmakers tried to expand on the Constitution's art.49 right to health care in chapter 3 of the proposed medical code, covering the basics of citizen's right to health care (art. 7), the rights of foreigners and stateless persons to health care (art. 8), guarantees of the right to health care (art. 9), restrictions on the citizens' health related rights (art. 10), citizens' health related responsibilities (art. 11). But problems remain with the proposed medical code. Firstly, articles 7-11 of the draft law are very short and lack details. Secondly, the Civil Code already explained the constitutional right to health care in articles 201, 270, 283286 [8]. Lawmakers should avoid duplication in the Civil Code and the Medical Code. They should expand on the Constitution's Article 49 provisions only in the Civil Code.

\section{Administrative Provisions of the Proposed Ukrainian} Medical Code

Article 49 of the Constitution not only declares the right to health services and medical assistance for every person, but also obligates the state to create conditions for effective and accessible medical services for all citizens. However, at present the organization of the health care system not only violates a person's constitutional right to accessible and high-quality medical care. The system also negatively affects Ukrainians' health and life expectancy. Furthermore, such an organisation hinders economic development and social solidarity [10-11]. The health care system therefore needs urgent reform.

The state should take the leading role in this reform. The supreme law validates the proposed medical code's 
importance for this reform, as 'the legal foundations for health care regulation are determined exclusively by the laws of Ukraine' (art. 92).

The successful reform, based on codifying existing medical legislation, depends on effective change management. The proposed medical code describes state health care regulation. In contrast to state governance of health care activities, state regulation encompasses a broader set of issues. Such a regulatory effect expands to the entire field of health care in the country. Such a field includes, according to Article 11 of the draft code, the entirety of health care institutions, as well as medical and other professionals, who work at those institutions or individuals, providing preventative medical services. The article also defines such a field to include bodies managing health care, which ensures direct state control, regulation and inter-sectoral participation in this specified field, as well as in the broader society.

The proposed medical code describes state health care regulation, aimed at enforcing a unified and effective state health care policy; the protection of the interests of the citizens who receive medical care, the creation of favorable conditions for the development and functioning of health care institutions under all forms of ownership and all organizational forms, ensuring opportunities for equal access to medical assistance for all social groups, the prevention of monopolization and the creation of conditions for fair competition in the health care system, ensuring transparency and openness in the health care system, as well all supporting integration into European and global health care systems.

These goals can be grouped into three blocks - state health care policy-related goals, goals related to improving health care, and goals related to the development of the health care system. Lawmakers should reformulate Article 12 of the Law the Fundamentals of Health Protection. The aims of state health care regulation should consist of: 1) running effective health care policy, 2) securing citizens' rights to health care and, 3 ) creating an effective system of health care.

Lawmakers of the proposed medical code should consider not only the norms of 1996 Constitution, but also the administrative provisions, including the Cabinet of Ministers' documents on public health. For now, the proposed medical code mentions that the public health is an essential goal for the country's health care system functioning - all organizations, institutions and resources, intended for provision of any type of service, aimed at strengthening, renewal and support of health at individual or collective level, including through intersectoral cooperation. According to the proposed medical code's provisions, 'the system of public health is a set of instruments, procedures and measures implemented by state bodies and non-governmental institutions that strengthen individual and public health, prevent the diseases, increase the life expectancy, active and productive living, encourage the healthy lifestyle through coordination the entire society's efforts'.

Government has to improve the administrative regulation of the state health care system using various means, including the legislative provisions on public health, their monitoring and forecasting of future actions.

It appears necessary to introduce corrections in the names of the corresponding sections, chapters and articles of the Medical code. It concerns the state policy in the sphere of protection of public health, organization of protection of public health and state regulation in this sphere in Ukraine.

The provisions concerning protection of public health and state regulation in the field can be found in section II of the Medical code. Their implementation may ensure harmonious development of physical and spiritual well-being, high productivity, long and active life of the citizens, removal of factors that negatively affect their health, reduction of morbidity rate, disability and mortality. This section is of declaratory character, is cumbersome and many of its provisions are duplicative.

Article 2 of the proposed medical code proclaims that protection of public health is a general duty of the state, citizens and society, and the state bodies and bodies of local self-government, enterprises, institutions and organizations of all forms of property, their officials (employees), citizens and groups of citizens are obliged to ensure the priority of health care in their activities.

Article 4 declares the main principles of functioning of the system of protection of public health in Ukraine, which include ensuring of effective health care as a priority of the state activities in the sphere of public services, patient needs-oriented approach, priority of prophylactic activities, ensuring quality medical help through standardization of medical practices, which are the general principles of the legislation o Ukraine in the sphere of protection of public health, and not only functioning of the system of health care. As regards the principles of equality of citizens, information openness, decentralization of power, legality, ensuring human and citizen's rights and enforcement of related social guarantees, these are constitutional principles that do not require duplication in the Medical code of Ukraine.

Article 13 of the Draft determines the forms of state regulation of protection of public health (licensing, control and monitoring, application of influence mechanisms, standardization, etc.), which are administrative legal methods, the application of which is regulated by the corresponding norms of administrative law and carried out by the executive bodies. Chapter 7 of the Draft "Licensing of activities in the sphere of health care" contains provisions on obligatory licensing of certain types of medical activity, list of documents necessary to receive a license, procedure of adopting a decision or rejection in issuing a license. It

\footnotetext{
${ }^{2}$ Such approach fully corresponds to the WHO guidelines, which combine traditional criteria of health - physical and mental, with the lifestyle of a person determined by social, economic and environmental circumstances.
} 
must be indicated that the corresponding relations are regulated by the Law of Ukraine "On licensing of certain types of commercial activities", Licensing conditions of commercial activities on medical practice, affirmed by the decree of the Cabinet of Ministers of Ukraine of 2 March 2016 No 285 , therefore it is unnecessary to fully regulate the matter by the Medical code, thus Articles 29-32 should be excluded from the proposed medical code, and Article 28 should be formulated as follows:

Article 28. Obligatory licensing

1. The authorized body shall under the procedure specified by the legislation of Ukraine and within the limits of its competence issue licenses to the economic entities for commercial activities on:

1) medical practice;

2) production of medical supplies, wholesale and retail sale of medical supplies;

3) development, production, manufacturing, storing, transportation, acquiring, sending, import, export, sale and destruction of narcotic substances, psychotropic substances and precursors.

This concerns also the provisions on influence measures. Articles 34-39 should be excluded from the proposed medical code, and Article 33 should be formulated as follows:

Article 33. Responsibility for violation of legislation on protection of public health.

The violation of legislation on protection of public health entails disciplinary, administrative, civil and criminal responsibility in accordance with the legislation of Ukraine.

The annulment of license to carrying out the activities on provision of medical services, removal of leadership from managing a medical institution, are measures of administrative responsibility foreseen by Article 30 of the Code of Ukraine on administrative offenses - "Deprivation of a special right granted to a citizen, deprivation of right to occupy certain positions or carry out certain activities".

It must be noted that except legal responsibility, the offenders may be affected by measures of influence in the form of administrative enforcement - temporary (till removal of offences) suspension of activities.

It must also be stated that Article 14 of the proposed medical code "Bodies that carry out state policy in the sphere of health care - management, regulation and coordination" has an incorrect name, as long as there is a state policy introduced in the sphere of protection of public health. Except for that, it is generally recognized that the state policy is the activity of the bodies of state power and management aimed at solution of social problems, achievement and realization of sustainable development of the society and its certain spheres, among which is the sphere of public health, while regulation and coordination are the functions of public administration, therefore, the name of the Article 14 should be formulated as follows: "Realization of state policy in the sphere of protection of public health".

Alongside with that, it appears that inclusion of Chapter 5 if fully justified, as it describes the powers of the executive bodies - of the authorized body and other central bodies of executive power and organs of local self-government in the sphere of public health care, their tasks and organization of activities, as well as Chapter 46 - "Participation of the public in healthcare management". Alongside with that, the duties of state bodies in the sphere of ensuring the rights of the public, including the duty to provide information at requests of interested natural and legal persons, needs a more detailed formulation.

\section{CONCLUSIONS}

The authors conclude that Ukraine needs a medical code incorporating international and European health care standards. Such a code will also further develop the country's medical legislation. Yet the proposed project has many constitutional and administrative weaknesses.

Lawmakers begin this document with the provisions that prove: health of each person in particular and public health in general are amongst the state's main values. Furthermore, the lawmakers attempted to specify the constitutional right to health protection. However, they have not taken into account the Civil Code, which already does it. Thus, the articles of the proposed medical code mostly duplicate it. As the articles of the proposed medical code do not contribute to specify the constitutional right to health care, it is advisable to exclude them from this document.

\section{REFERENCES}

1. Maidanyk R. A. Zakonodavstvo Ukrainy v sferi okhorony zdorov'ia: systema i systematyzatsiia [Ukrainian Legislation on Health Care: System and Systematisation]. Medychne pravo. 2013; 2: 63-74. (In Ukrainian).

2. Buletsa S.B. Tsyvilni pravovidnosyny, shcho vynykaiut u sferi zdiisnennia medychnoi diialnosti: teoretychni ta praktychni problemy: dys. ... dokt. yuryd. nauk [Civil Relationships on Medical Diagnostics: Theoretical and Practical Problems. Ph.D. Thesis]. Odesa. 2016; 437. (In Ukrainian).

3. Hladun Z. S. Do pytannia pro zmist administratyvno-pravovykh norm u sferi okhorony zdorov'ia naselennia [0n Problem of Administrative Norms in the Health Care]. Naukovyi visnyk Lvivskoi komertsiinoi akademii. Seriia : Yurydychna. 2015; 2: 133-144. (In Ukrainian).

4. Deshko L. Patenting of medical products: the experience of implementation of the flexible provisions of the TRIPS -plus Agreement by foreign countries and the fundamental patent reform in Ukraine. Georgian Medical News. 2018; 9: 161-164. (In Ukrainian).

5. Stetsenko S.H. Medychne pravo Ukrainy : pidruchnyk [Medical Law of Ukraine: Textbook] / Za zah. red. d.yu.n., prof. S. H. Stetsenka, V. Yu. Stetsenko, I. Ya. Seniuta. Vseukrainska asotsiatsiia vydavtsiv „Pravova yednist". 2008; 507. (In Ukrainian).

6. Sarybaieva H.M. Administratyvne zakonodavstvo u sferi okhorony zdorovia: stan kodyfikovanosti [Administrative Legislation in Health Care: Codification]. Jurnalul Juridic Național: teorie şi practică. 2017; 6 (1): 60-62. (In Ukrainian).

7. Konstytutsiia Ukrainy 1996 [Constitution of Ukraine 1996]. Vidomosti Verkhovnoi Rady Ukrainy. 1996; 30: 142.

8. Proekt Zakonu Ukrainy «Pro vnesennia zmin do Osnov zakonodavstva pro okhoronu zdorov'ia» - «Medychnyi kodeks» [Project Law of Ukraine 'On Amendments of Basics of Healt Care Legislation'-'Medical Code']. Available from: https://www.apteka.ua/article/7780 (In Ukrainian). 
9. U spravi za konstytutsiinym podanniam 66 narodnykh deputativ Ukrainy shchodo vidpovidnosti Konstytutsii Ukrainy (konstytutsiinosti) Postanovy Kabinetu Ministriv Ukrainy «Pro zatverdzhennia pereliku platnykh posluh, yaki nadaiutsia v derzhavnykh zakladakh okhorony zdorovia ta vyshchykh medychnykh zakladakh osvity» (sprava pro platni medychni posluhy): Rishennia Konstytutsiinoho Sudu Ukrainy vid 25 lystopada $1998 \mathrm{r}$. [Decision of the Constitutional Court of Ukraine, In the Case of the Constitutional Petition of 66 people's deputies of Ukraine on the Constitutionality of Cabinet of Ministers Resolution 'On approval of the list of paid services provided in public health care institutions and higher educational institutions', Document v015p710-98, November 25, 1998)] Ofitsiinyi visnyk Ukrainy. 1998; 50: 1854. (In Ukrainian).

10. U spravi za konstytutsiinym podanniam 53 narodnykh deputativ Ukrainy shchodo ofitsiinoho tlumachennia polozhennia chastyny tretoi statti 49 Konstytutsii Ukrainy «u derzhavnykh i komunalnykh zakladakh okhorony zdorovia medychna dopomoha nadaietsia bezoplatno» (sprava pro bezoplatnu medychnu dopomohu): Rishennia Konstytutsiinoho Sudu Ukrainy vid 29 travnia 2002 r. [Decision of the Constitutional Court of Ukraine, On the Case of the Constitutional petition of 53 People's Deputies Regarding the Official interpretation of the Provisions of Article 49.3 of the Constitution of Ukraine, Document v010p710-02, May 29, 2002]. Ofitsiinyi visnyk Ukrainy. 2002; 23: 1132. (In Ukrainian).

11. Tsyvilnyi kodeks Ukrainy [Civil Code of Ukraine]. Vidomosti Verkhovnoi Rady Ukrainy. 2003; 40-44: 356. (In Ukrainian).

12. Kontseptsia reformi finansuvannyia sistemi gromadskogo zdorovia [The Concept of reform of financing the health care system of 30 November 2016 No 1013-p]. Ofizijny visnik Ukrainy. 2017. 2: 50. (In Ukrainian).

13. Kontseptsia rozvitku sistemi gromadskogo zdorovia [The Concept of development of the public health system of 30 November 2016 p. № 1002-p]. Urjadovy kurier. 2017. 8: 13. (In Ukrainian).

14. Zakon Ukraini 'Pro litsenzuvannia vidiv gospodarskoji dijalnosti' [The Law of Ukraine 0n licensing of certain types of commercial activities of 02.03.2015 No 222-VIII]. Vidomosti Verkhovnoi Rady Ukrainy. 2015; 23: 158. (In Ukrainian).

15. Litsenzijni umovi provadjennia gospodarskoji dijalnosti z medichnoji practiki [The licensing conditions for implementation of commercial activities in medical practice of 2 March 2016 № 285]. Ofizijny visnik Ukrainy. 2016. 30: 1184. (In Ukrainian).
16. Kodeks Ukrainy 'Pro administrativni pravoporushennia' [The Code of Ukraine on administrative offences of 07.12.1985]. Vidomosti Verkhovnoi Rady Ukrains'koi RSR. 1984. Annex to No 51: 1122.

This research is the part of the National University "Odessa Academy of Law"'s researches on the topic "Strategy of Ukraine's Integrational Development: Legal and Cultural Dimensions» (state registration number 0116U001842), 2016-2020.

\section{ORCID and contributionship:}

Natalia V. Mishyna - 0000-0002-2357-3384 ${ }^{A, B, D, E, F}$

Olena O.Surilova - 0000-0001-7071-6678 ${ }^{A, B, D, E, F}$

\section{Conflict of interest:}

The Authors declare no conflict of interest

\section{CORRESPONDING AUTHOR Natalia V. Mishyna}

Department of Constitutional Law, National University «0desa Law Academy» street Pionerskaya, 2, kb. 405, 65009, 0desa, Ukraine tel: +380953636414

e-mail:mishyna@ukr.net

Received: 21.02.2019

Accepted: 04.11.2019

A - Work concept and design, B - Data collection and analysis, C - Responsibility for statistical analysis, D-Writing the article, $\mathbf{E}$-Critical review, $\mathbf{F}$ - Final approval of the article 